\title{
Predation by crustaceans on a newly settled 0-group plaice Pleuronectes platessa population in the western Wadden Sea
}

\author{
Henk W. van der Veer \& Magda J. N. Bergman \\ Netherlands Institute for Sea Research, PO Box 59, NL-1790 AB Den Burg Texel, The Netherlands
}

\begin{abstract}
Predation by the brown shrimp Crangon crangon causes a significant density-dependent mortality of 0-group plaice during and shortly after settling on tidal flats in the western Wadden Sea between February and May. Evidence was obtained from (1) laboratory experiments indicating that larger shrimps are able to prey on plaice $\leqslant 30 \mathrm{~mm}$; (2) field observations showing that each year the period of density-dependent mortality ends in May-June when the plaice population has reached a mean size of about $30 \mathrm{~mm}$; (3) the occurrence of fin damage in the field, characteristic of unsuccessful attacks by shrimps, according to laboratory experiments; and (4) shrimp stomachs containing significant numbers of plaice otoliths. The shrimp predation is density-dependent and accounts for the total mortality in plaice $\leqslant 35 \mathrm{~mm}$ as estimated in a previous paper (van der Veer 1986). The observed dependence of mortality on density appears to be caused by the combined effect of a functional and numerical response of the predator to fluctuations in plaice density. The number of fin damages of a plaice does not seem to influence its survival. Predation by larger crabs seems to be of minor importance and occurs only after May. Shrimp predation appears to act as a fine control mechanism reducing between-year variations in year-class strength generated in the egg or larval stages in the open sea.
\end{abstract}

\section{INTRODUCTION}

The main spawning grounds of North Sea plaice Pleuronectes platessa L. are located in the Southern Bight and eastern English Channel. Once released in January-February, the developing eggs and larvae are transported by residual currents in a northeasterly direction towards coastal nurseries (Simpson 1959, Harding et al. 1978, Talbot 1976, 1978). In these nursery areas, of which the Wadden Sea is probably the most important (Zijlstra 1972), the larvae settle in the tidal zone and remain there during their first years of life (Bückmann 1934, Rauck 1974, Kuipers 1977 , Creutzberg et al. 1978). Similar behaviour has been observed in other shallow coastal areas (e.g. Macer 1967, Edwards \& Steele 1968, Lockwood 1972).

Large fluctuations can be observed in year-class strength after recruitment, which points to differences in the numbers surviving during early life (Beverton 1961, Bannister 1978, Rauck \& Zijlstra 1978). These differences seem to originate from the egg or early larval phase in the open sea (Rauck \& Zijlstra 1978,
Brander \& Houghton 1982, Zijlstra \& Witte 1985). They generate between-year variations in the supply of larvae to coastal nurseries. In these nurseries, evidence has been found for density-dependent mortalities among the juvenile plaice stock, which tend to reduce the between-year differences generated in the pelagic stages (e.g. Riley \& Corlett 1966, Rauck \& Zijlstra 1978, Lockwood 1980, Zijlstra et al. 1982, van der Veer 1986).

In the western part of the Wadden Sea, densitydependent mortality seems to occur mainly during the arrival of larvae and shortly after settling (Zijlstra et al. 1982, van der Veer 1986). Two mortality factors have been reported which might be responsible for densitydependent effects. Both are related to the phenomenon that in years with a large larval influx the period of arrival is relatively delayed. (Zijlstra \& Witte 1982, van der Veer 1985).

One factor operates in the pelagic phase. Larval immigration appears to be broken off at the beginning of May due to predation by some coelenterate species that show outbursts in the coastal zone each year at that time (van der Veer 1985). In years with a high 
abundance of larvae associated with a late larval arrival, coelenterate predation will affect a relatively larger part of the population.

The second factor operates after the settling of larvae on the tidal flats. During the first weeks newlymetamorphosed plaice remain on the flats during the whole tidal cycle, but gradually a tidal migration rhythm develops, the juvenile fish migrating to the deeper tidal gullies and channels at low tide (van der Veer \& Bergman 1986). In years of strong larval immigration, the last groups of immigrants may meet increasingly unfavourable conditions (low oxygen saturation levels and high temperatures) directly after settling on the tidal flats at low tide, that may lead to mortality (e.g. Berghahn 1983).

However, both mortality factors operate only at the end of the larval arrival in April-May and cannot explain the density-dependent mortalities observed during the period of larval immigration from February to April-May. Predation by brown shrimps Crangon crangon and shore crabs Carcinus maenas has also been suggested as an important mortality factor in 0 group plaice in the western Wadden Sea (Bergman et al. 1976).

In the present paper this predation will be considered in more detail on the basis of stomach content analysis of Crustacea collected in the field and of preypredator experiments in the laboratory.

\section{MATERIAL AND METHODS}

Experiments. Predator-prey experiments were carried out under simplified conditions in darkness at a temperature of 15 to $18^{\circ} \mathrm{C}$ in plastic containers of $0.25 \mathrm{~m}^{2}$ or $2.5 \mathrm{~m}^{2}$ containing $5 \mathrm{~cm}$ of aerated seawater. No layer of sand was put on the bottom, because otherwise the small plaice would hardly be detectable. The plaice and Crustacea were collected freshly on tidal flat areas near the institute and adapted to laboratory conditions for $24 \mathrm{~h}$ before starting an experiment.

The influence of predator size on predation rate was investigated by comparing the predation rate by 10 shrimps on 10 plaice of different size groups. Twelve $h$ after introduction of the predators with the 10 potential preys, the numbers of plaice remaining were recorded. Each combination of predator and prey was tested at least 3 times.

The influence of prey density on predation rate was investigated by offering a variable density of plaice in the size range 10 to $15 \mathrm{~mm}$ to 10 shrimps in the size range 41 to $45 \mathrm{~mm}$. Densities of plaice varied from 1 to 32 per container. Most experiments were carried out in containers of $0.25 \mathrm{~m}^{2}$, but at the lowest densities $<8$ $\mathrm{m}^{-2}$ ) tanks with a size of $2.5 \mathrm{~m}^{2}$ had to be used. Each experiment lasted for at least $36 \mathrm{~h}$ and was repeated 8 to 25 times. At fixed time intervals the number of plaice surviving was counted and the missing ones were replaced by new specimens. The frequency of observation was based on a digestion experiment carried out with shrimps under similar laboratory conditions at $18^{\circ} \mathrm{C}$ (see Fig. 4).

Field observations. The seasonal variations in abundance of plaice and Crustacea on the Balgzand, a large tidal flat area in the western Wadden Sea, The Netherlands (Fig. 1), were recorded by regular sampling on a grid of 36 stations distributed over the whole

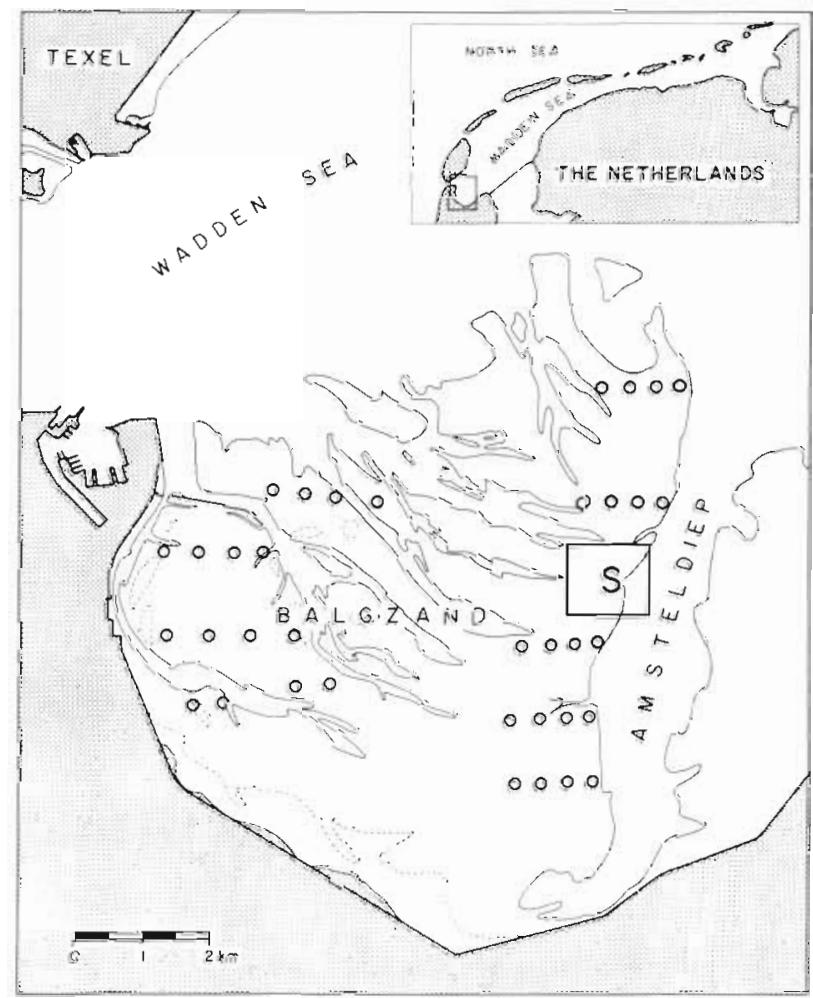

Fig. 1. Location of the Balgzand tidal flat area in the western Wadden Sea. Sampling stations on the whole area (O) and the selected quadrat on the eastern part (S) are indicated

area at 2 wh intervals around high water from 1979 to 1982. Mean water depth at high tide was about 1 to $1.5 \mathrm{~m}$, depending on lunar phase and prevailing weather conditions. More details of the area and the sampling procedure are given in van der Veer (1986). Migratory behaviour of plaice and Crustacea was studied on a fixed rectangle of about $1 \mathrm{~km}^{2}$ on the eastern side of the Balgzand (Fig. 1). The area consisted of tidal flats, bordered in the east by the main tidal channel (Amsteldiep), in the north and south by small tidal gullies and in the west by a watershed. The flats are not completely drained at low water; locally 
areas with shallow pools of about 1 to $5 \mathrm{~cm}$ of water remain, called 'inner lakes'. More details of area and procedure are given in van der Veer \& Bergman (1986). The distribution of plaice, shrimp and crab during a tidal cycle was followed by sampling with fishing gear on the tidal flats, the gully and the channel. The stations were fished weekly every second hour for $24 \mathrm{~h}$ in 1980

The gear used was a $1.9 \mathrm{~m}$ beam trawl (mesh size 5 $\times 5 \mathrm{~mm}$ ) on all 36 stations on the whole Balgzand and a $1 \mathrm{~m}$ beam trawl (mesh size $3 \times 3 \mathrm{~mm}$ ) in the selected rectangle, using a rubber dinghy with a $25 \mathrm{hp}$ outboard motor at a water depth of over $50 \mathrm{~cm}$. In shallower waters the net was towed by hand. The catch was sorted immediately and plaice were preserved in $70 \%$ alcohol and within a week measured to the nearest $\mathrm{mm}$ total length. Shrimps and crabs were killed by putting them in boiling water for a few seconds to prevent regurgitation of stomach contents, preserved in $4 \%$ neutral formaldehyde solution, and measured in size classes of $5 \mathrm{~mm}$, length and carapace width respectively. For both gears, the numbers of plaice caught were corrected for net efficiency according to Kuipers (1975), Dapper (1978) and van der Veer \& Bergman (1986). Shrimp and crab data were only corrected for mesh selection of the $5 \times 5 \mathrm{~mm}$ net for shrimps, according to Kuipers \& Dapper (1981). All numbers were expressed in numbers per $1000 \mathrm{~m}^{2}$ (ind $1000 \mathrm{~m}^{-2}$ ) for the whole area and per $100 \mathrm{~m}^{2}$ (ind $100 \mathrm{~m}^{-2}$ ) for the selected rectangle. Details of the tidal behaviour of plaice have already been published (van der Veer \& Bergman 1986).

To obtain an estimate of plaice mortality due to shrimp predation, the stomach contents of shrimps $>30$ $\mathrm{mm}$ were examined for plaice remains (otoliths) in day and night-time catches collected at high and low water on the selected area from the period February to May 1980. In order to estimate the actual length of the plaice consumed from the otoliths, the linear relation between length of the main otolith, the sagitta $(\mathrm{S} ; \mathrm{mm})$, and plaice size ( $\mathrm{L} ; \mathrm{mm})$ was determined: $\mathrm{S}=$ $0.0305 \mathrm{~L}-0.15\left(\mathrm{r}_{\mathrm{s}}=0.99 ; \mathrm{p}<0.001\right)$.

\section{RESULTS}

\section{Experiments}

Effect of prey and predator size on predation rate

The results of the experiments with Crangon crangon as predator are shown in Fig. 2. Generally predation rate increased with increasing size of the shrimps and, except for the largest shrimps, small plaice were more vulnerable than larger ones. Even the largest shrimps $(70 \mathrm{~mm})$ were not able to consume plaice over $30 \mathrm{~mm}$ in length. The minimum size of shrimps which could feed on 0-group plaice was about $30 \mathrm{~mm}$.

With Carcinus maenas less extensive experiments were carried out (Fig. 3). Crabs larger than $26 \mathrm{~mm}$ carapace width were capable of preying on the smallest plaice offered (16 to $20 \mathrm{~mm}$ ). Plaice of 51 to $55 \mathrm{~mm}$ in length were outside the predation range for crabs, even for the largest specimens used (46 to $50 \mathrm{~mm}$ carapace width).

\section{Effect of prey density on predation rate}

The time interval between censuses in the predation experiments was determined on the basis of a digestion experiment, in which shrimps of 41 to $45 \mathrm{~mm}$ were fed small plaice after a starvation period of $48 \mathrm{~h}$. Remains of consumed plaice - mainly fin rays and otoliths - were detectable for about 2.5 to 3.0 h (Fig. 4).
Fig. 2. Crangon crangon/Pleuronectes platessa. Mean predation rate (ind $12 \mathrm{~h}^{-2}$ ) of 10 shrimps on plaice at $18^{\circ} \mathrm{C}$ as a function of the sizes of the 2 species, based on 3 to 12 observations for each combination

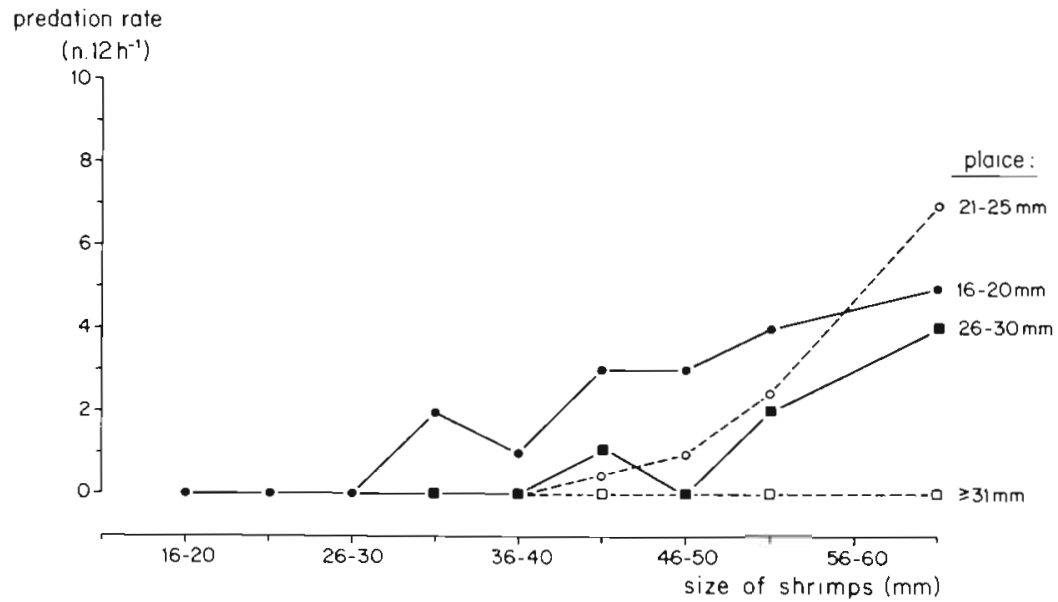




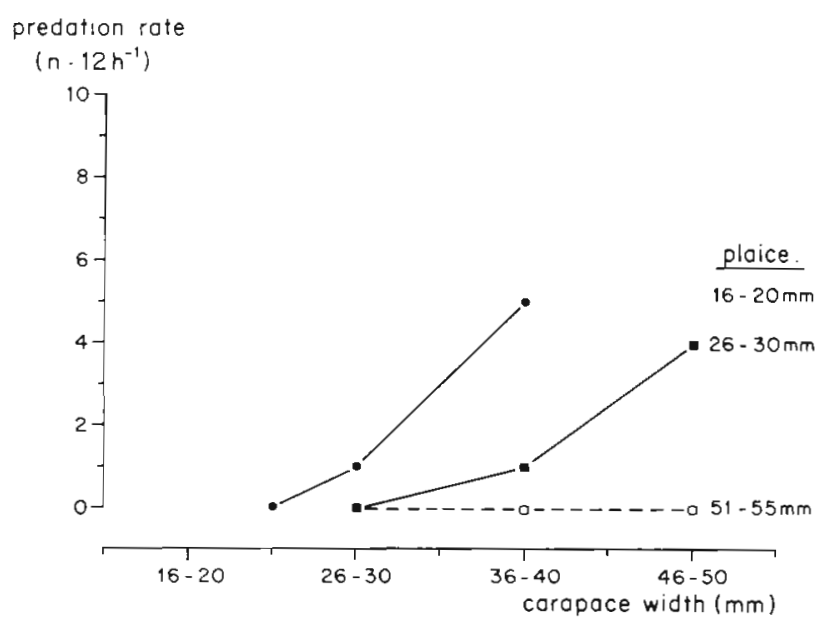

Fig. 3. Carcinus maenas/Pleuronectes platessa. Mean predation rate (ind $12 \mathrm{~h}^{-1}$ ) of 10 crabs on plaice at $18^{\circ} \mathrm{C}$ as a function of the sizes of the 2 species, based on 3 to 5 observations for each combination

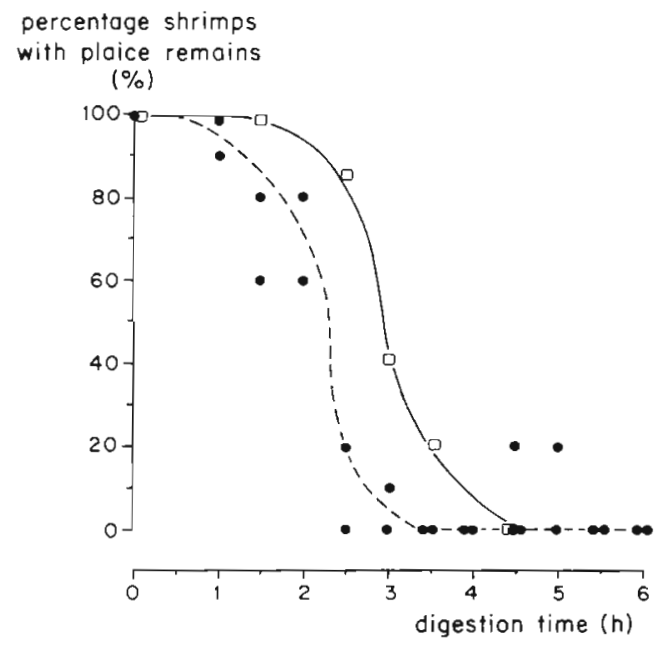

Fig. 4. Crangon crangon/Pleuronectes platessa. Digestion time of plaice by shrimps of 41 to $45 \mathrm{~mm}$ under various starvation conditions at $18^{\circ} \mathrm{C}$. Lines drawn by eye. (•) Starved for $48 \mathrm{~h}$; ( $\square$ ) starved for $24 \mathrm{~h}$

After a starvation period of $24 \mathrm{~h}$, digestion time was increased to about $3.5 \mathrm{~h}$. It was assumed that for unstarved shrimps digestion time would be in the order of $4 \mathrm{~h}$ and this time interval was used.

The results of the predation experiments were rather variable for the first $12 \mathrm{~h}$, because the shrimp had been starved. Therefore, these data were omitted. All numbers consumed were converted into numbers consumed per shrimp, and the arithmetic mean values were estimated with $95 \%$ confidence limits.

Fig. 5 gives the functional response of shrimp predation in relation to plaice density for the plaice size group 11 to $15 \mathrm{~mm}$. Below a plaice density of $4 \mathrm{~m}^{-2}$ predation rate was virtually zero, but above predation

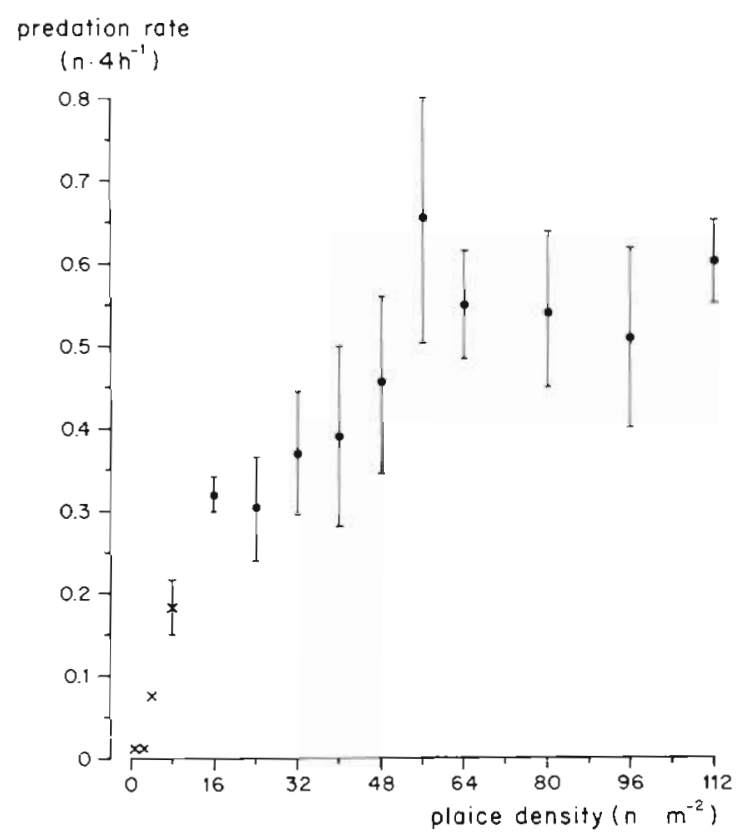

Fig. 5. Crangon crangon/Pleuronectes platessa. Functional response of the predation by 10 shrimps of 41 to $45 \mathrm{~mm}$ (ind $4 \mathrm{~h}^{-1}$ ) in relation to plaice density for plaice of 10 to $15 \mathrm{~mm}$. (x) Tanks of $2.5 \mathrm{~m}^{2}$; (๑) tanks of $0.25 \mathrm{~m}^{2}$. Mean values with $95 \%$ confidence limits

increased abruptly up to a level of about 0.65 plaice per $4 \mathrm{~h}$ per shrimp. At prey densities of about $48 \mathrm{~m}^{-2}$ the number of plaice consumed per shrimp remained more or less constant and evidently represented the maximum intake capacity of the 10 shrimps used in the experiment.

\section{Evidence of unsuccessful attacks by predators}

In the experiments described those plaice which survived did not all remain undamaged: some showed typical fin and tail damage (Fig. 6). To determine

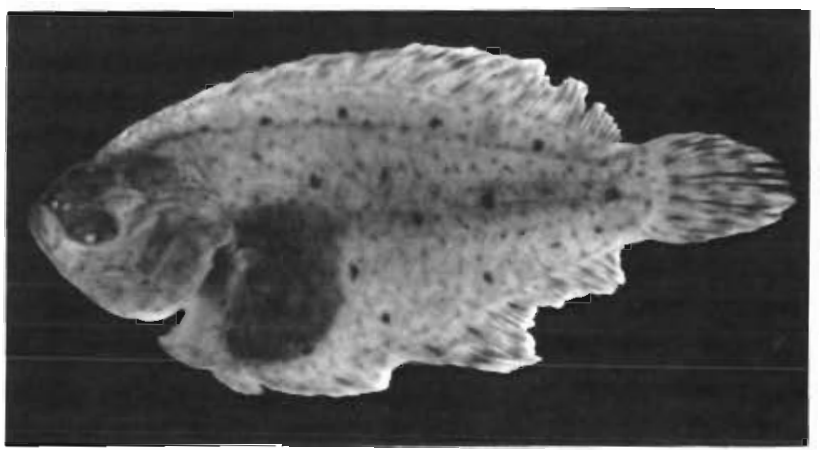

Fig. 6. Pleuronectes platessa. A newly-settled 0-group plaice (19 $\mathrm{mm})$ with typical fin damage 
whether the damage was due to unsuccessful attacks by shrimps or to attacks from other plaice, 10 undamaged plaice of 26 to $30 \mathrm{~mm}$ (less susceptible to predation by shrimps, see Fig. 2) were put together with 10 shrimps of 51 to $55 \mathrm{~mm}$ in one container and with 10 plaice of 11 to $15 \mathrm{~mm}$ in another. After $12 \mathrm{~h}$ all plaice were examined for tail and fin damage. The experiment was repeated 4 times. Damage was only observed when shrimps were present, and it is therefore concluded that these resulted from attacks by shrimps.

The rate of recovery from such damage was studied in an experiment in which various size classes of plaice were held in different containers, and inflicted with wounds on their fins and tails comparable to those resulting from attacks. Regular inspection revealed that the damage disappeared in the course of time, at a similar rate for all size classes (Fig. 7). Most of these

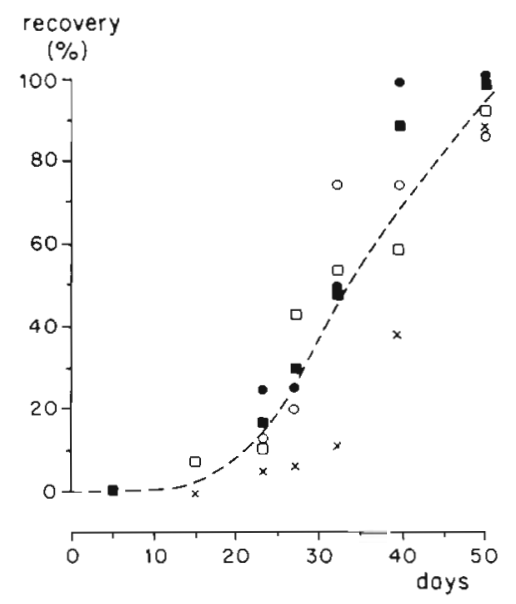

Fig. 7. Pleuronectes platessa. Recovery $(\%)$ of plaice from artificially inflicted fin damage under laboratory conditions for a number of different size groups ( $16-20 \mathrm{~mm} ; 0: 21-25$ $\mathrm{mm} ; \square: 26-30 \mathrm{~mm} ; \mathbf{a}: 31-35 \mathrm{~mm} ; \times: 36-40 \mathrm{~mm}$ )

plaice appeared to have completely recovered within $50 \mathrm{~d}$.

\section{Field investigations}

\section{Abundance}

To determine the interactions between 0 -group plaice and their potential crustacean predators (shrimps $>30 \mathrm{~mm}$ and crabs $>25 \mathrm{~mm}$ ) in the Wadden Sea, the seasonal trends in plaice and predator abundance were determined (Fig. 8). During the period of settlement before May only shrimps were present in moderate densities (about 250 to 500 ind $1000 \mathrm{~m}^{-2}$ ). Predatory crabs were absent before the end of April
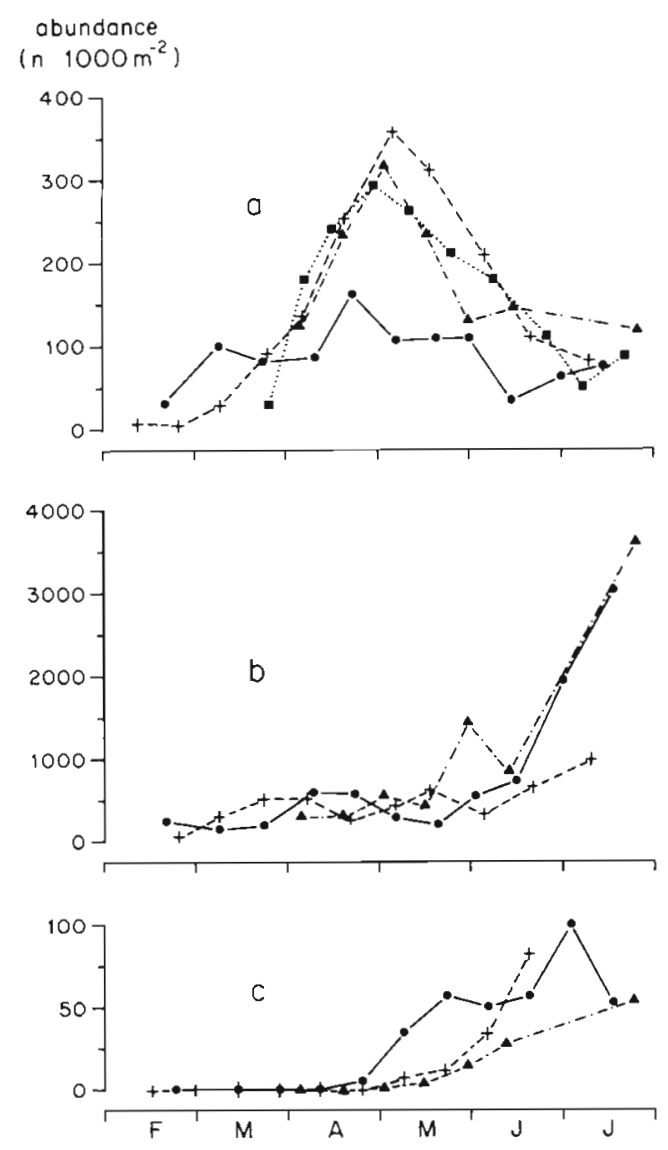

Fig. 8. Mean abundance (ind $1000 \mathrm{~m}^{-2}$ ) of (a) 0-group plaice Pleuronectes platessa, and its potential predators (b) Crangon crangon $\geqslant 31 \mathrm{~mm}$ and (c) Carcinus maenas $\geqslant 26 \mathrm{~mm}$ on the Balgzand at high water during Feb to Jun in 1979 (A), 1980 (•), $1981(+)$ and 1982(

and even then their densities stayed far lower than those of Crangon crangon. Therefore, the most important of both potential predators in the field till May is C. crangon.

\section{Tidal behaviour}

Fig. 9, $10 \& 11$ show the high and low water distributions of 0 -group plaice $\leqslant 30 \mathrm{~mm}$ and the 2 potential predators in the selected rectangle. Until May large numbers of small plaice were present on the tidal flats and especially the inner lakes at high water, during both day and night. In the tidal gully and channel only low numbers were found. At low water plaice could be found in the inner lakes and the tidal channel in large numbers, but highest densities were present in the tidal gully with up to 1200 ind $100 \mathrm{~m}^{-2}$. No systematic differences could be observed between day and nighttime.

From the first appearance of plaice in March, shrimps $>30 \mathrm{~mm}$ were found in the intertidal zone at 

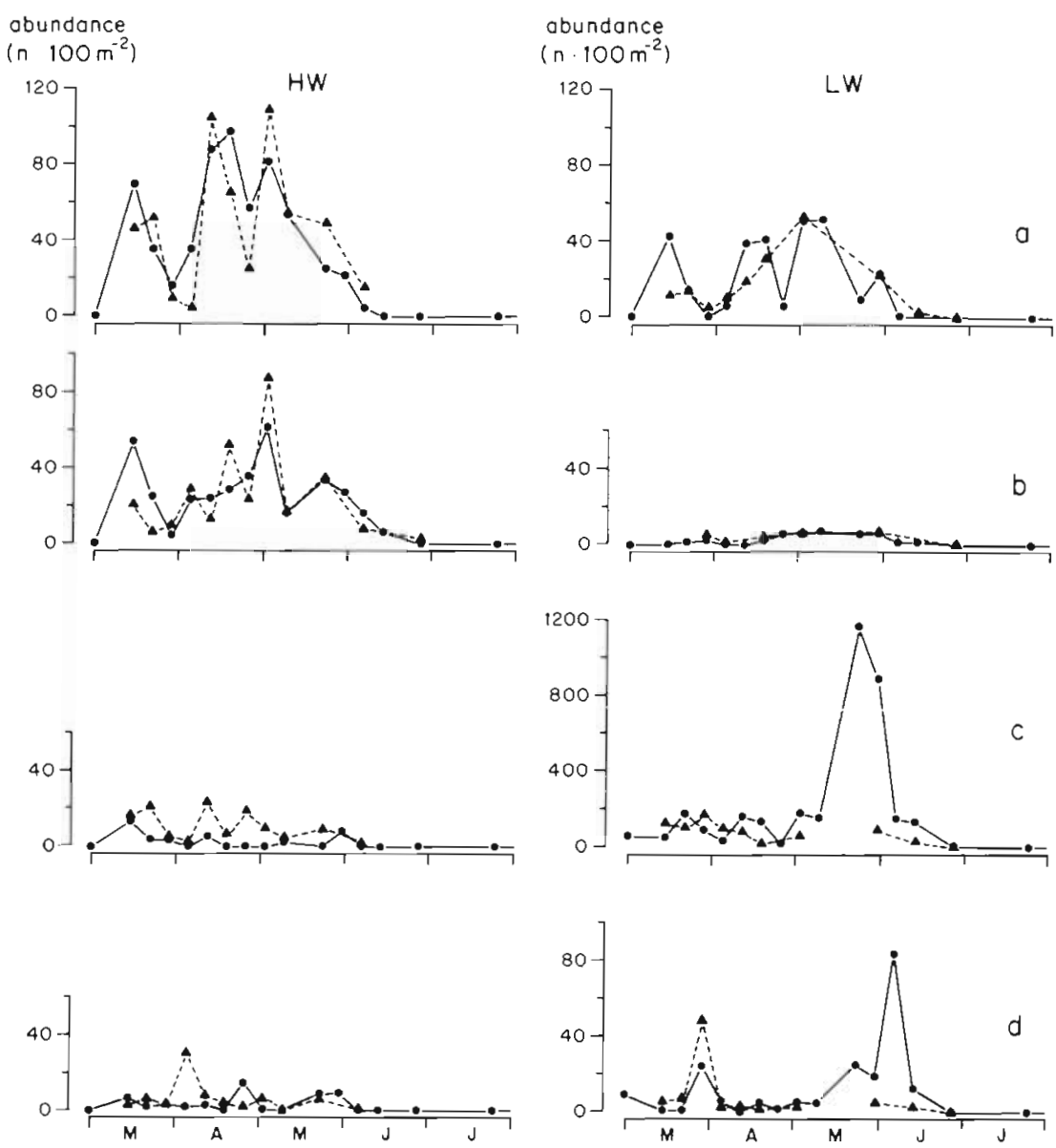

Fig. 9. Pleuronectes platessa. Mean abundance (ind $100 \mathrm{~m}^{-2}$ ) of 0 -group plaice $\leqslant 30 \mathrm{~mm}$ on the selected area at high and low water during day $(-)$ and night (---). (a) Inner lake; (b) drained tidal flat; (c) tidal gully; (d) tidal channel

high water at densities of 50 to 100 ind $100 \mathrm{~m}^{-2}$ both on the drained flats and on the inner lake (Fig. 10). During March to June densities fluctuated considerably. In the tidal gully and channel densities were about twice those on the flats. Night catches were slightly higher than daytime catches on the flats. At low water, hardly any larger sized shrimps were found on the flats until June, but large numbers were present in the gully and channel in densities of about twice those at high water. No consistent trend was observed between day and night-time. From June onwards, densities increased sharply both during high and low water, except on the flats at low water during daytime.

Crabs $>25 \mathrm{~mm}$ were not present before the beginning of May and afterwards only in far lower numbers than shrimps (Fig. 11). At high tide crab densities of about 10 ind $100 \mathrm{~m}^{-2}$ were estimated on the tidal flats and a consistent difference was observed between day and night catches with larger numbers present during the night. At low water virtually all crabs had disappeared from the catches. During both high and low tide highest densities were observed in the tidal gully and channel, varying between 50 and 200 ind $100 \mathrm{~m}^{-2}$.

\section{Plaice with fin damage}

All plaice caught on the selected rectangle were carefully examined for possible fin damage (Fig. 12). In March approximately $60 \%$ of the plaice showed one or more wounds, decreasing only gradually to $50 \%$ in early May. Subsequently, the percentage wounded fish declined consistently until no fin damage was observed by the end of June.

If these fin wounds do not affect the chance of the plaice being subsequently successfully attacked and consumed by shrimps, the distribution of fin wounds over the plaice population should reflect a random distribution. Since the mean number of wounds per fish in the population is generally $<1$, the observed frequency distributions of the number of fin damages should agree with Poisson series. For testing the hypothesis of randomness the newly-settled plaice ( $\leqslant 15 \mathrm{~mm}$ ) represent the most suitable group, because they suffer the heaviest mortalities and their numbers are continuously replenished by new and undamaged settlers. In 8 out of the $9 \mathrm{wk}$ of study, the observed distributions did not differ significantly from the 

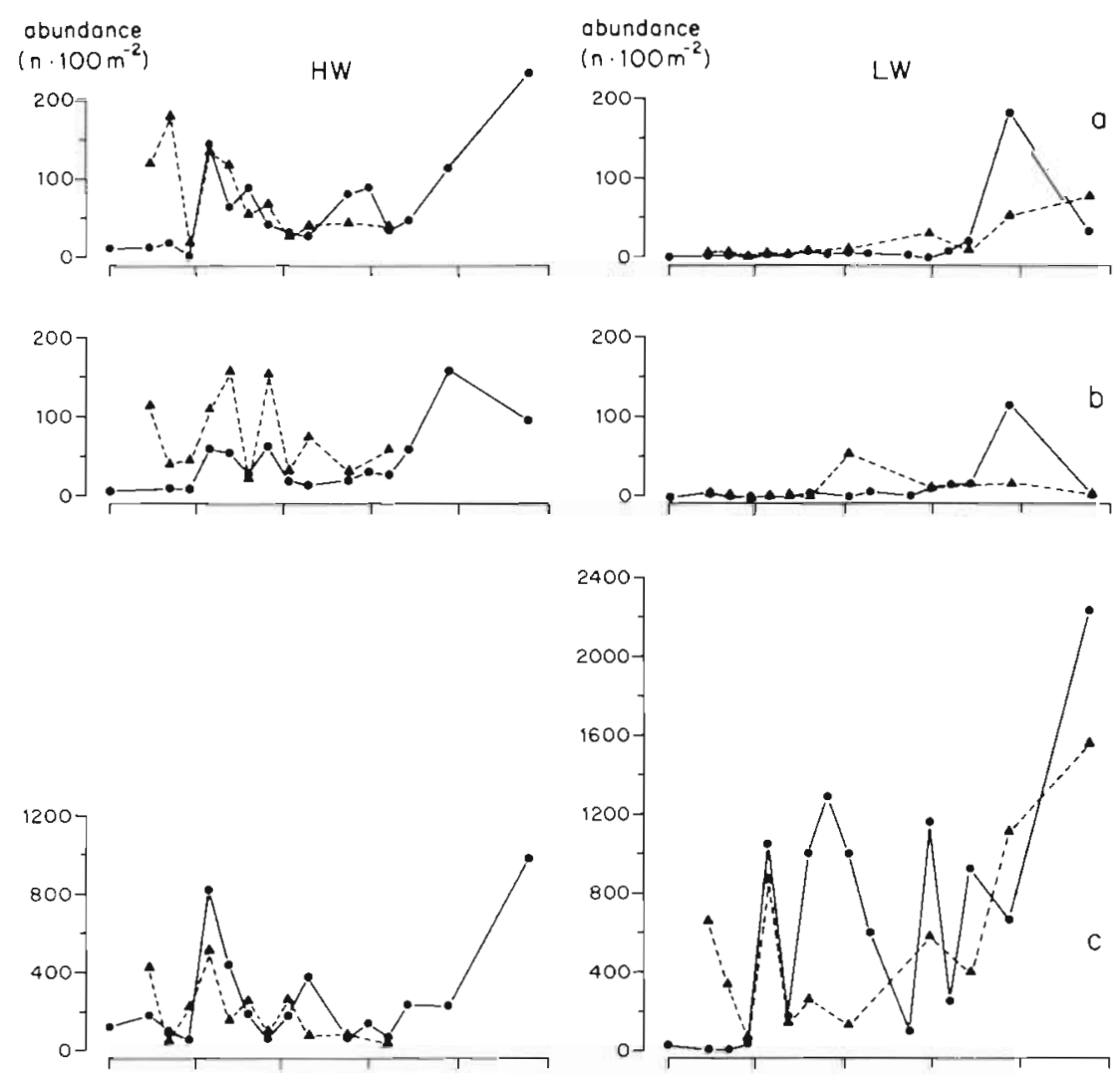

Fig. 10. Crangon crangon. Mean abundance (ind $100 \mathrm{~m}^{-2}$ ) of shrimp $\geqslant 31 \mathrm{~mm}$ on the selected area at high and low water during day $(-)$ and night $(--)$. (a) Inner lake; (b) drained tidal flat; (c) tidal gully; (d) tidal channel

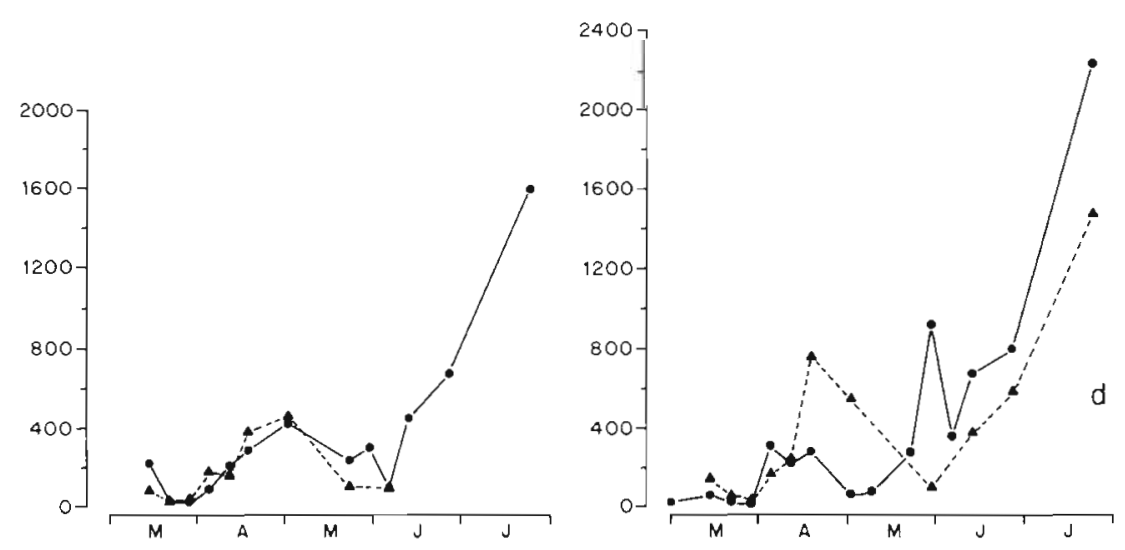

expected Poisson series (Table 1). This indicated that fin wounds do not have any influence on the chance of escaping from a subsequent attack by shrimps.

\section{Stomach content analysis of shrimps}

Fin rays were found in shrimp stomachs together with sagittae, and sometimes the smaller otoliths (utriculus and lagena) were also found. Plaice is the only flatfish species found on the selected rectangle, so confusion with other species was not possible.

Table 2 shows for various size groups of shrimps the number of stomachs checked and the quantity of plaice remains found. A total of 2379 stomachs were analysed and about $5 \%$ of the shrimps had recently consumed a plaice. Assuming a digestion time of about $1 \mathrm{~d}$ (see Fig. 14), this would mean that, at a mean shrimp density of about 50 ind $100 \mathrm{~m}^{-2}$ (Fig. 10) on the selected rectangle during the period February to June, every day about 2.5 plaice per $100 \mathrm{~m}^{2}$ were consumed. Such a mortality would cause the observed decline on the whole Balgzand in 1980 (from 160 to 75 ind $1000 \mathrm{~m}^{-2}$ ) in $4 \mathrm{~d}$. In Fig. 13 the size frequency distribution of the plaice was plotted for each size group of shrimps, estimated from the otolith length found in the shrimp stomachs. 

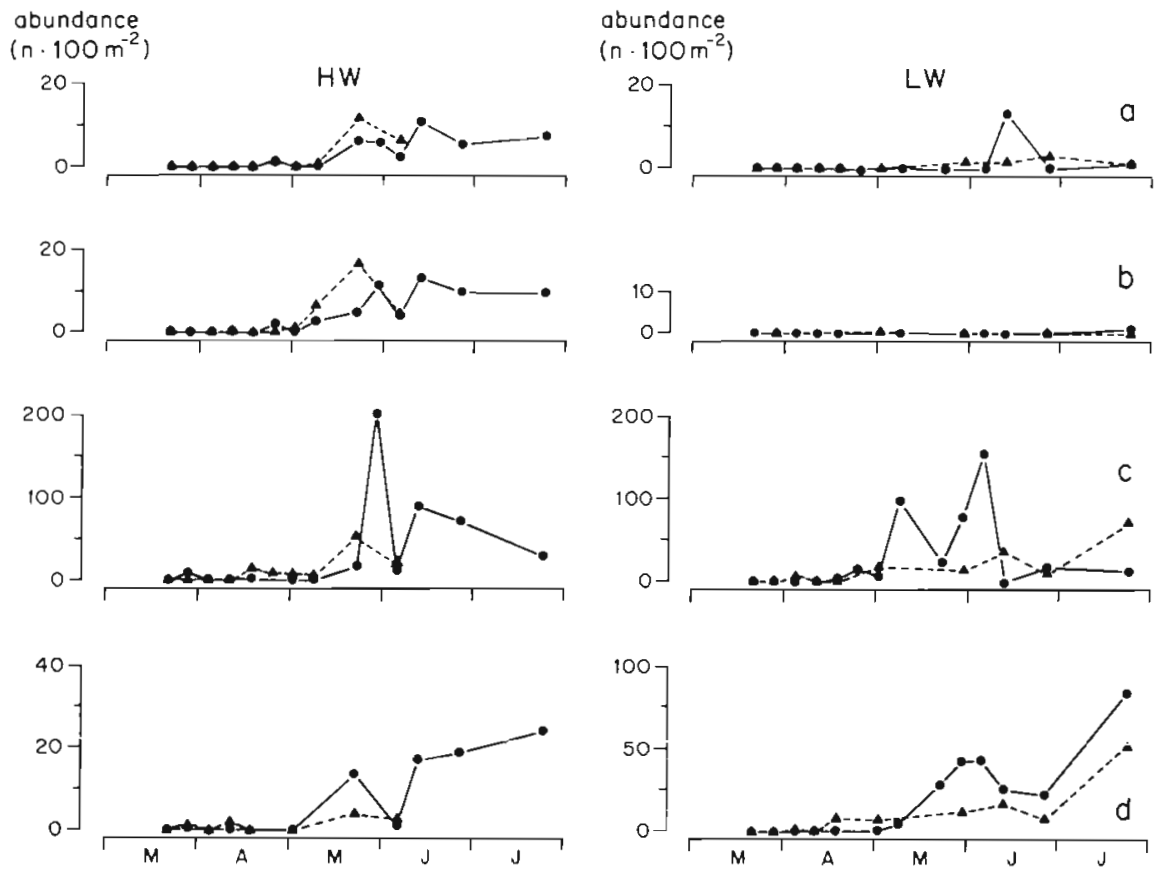

Fig. 11. Carcinus maenas. Mean abundance (ind $100 \mathrm{~m}^{-2}$ ) of crabs $\geqslant 26$ $\mathrm{mm}$ on the selected area at high and low water during day (-) and night $(--)$. (a) Inner lake; (b) drained tidal flat; (c) tidal gully; (d) tidal channel

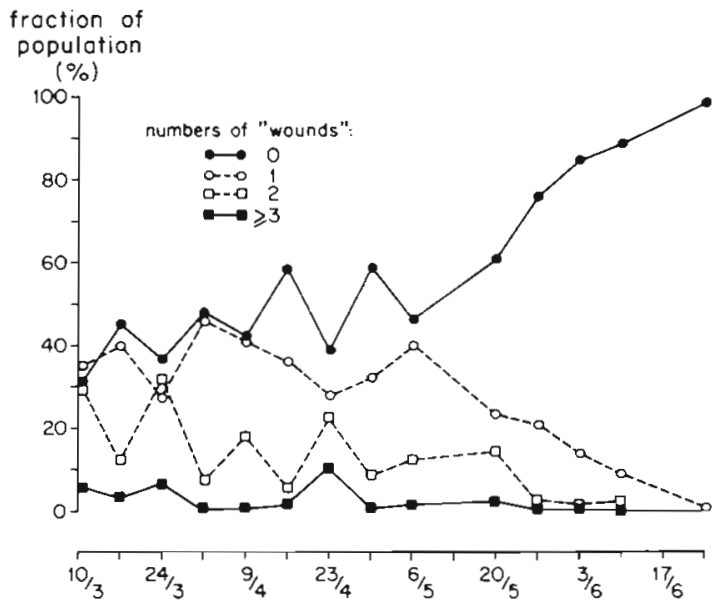

Fig. 12. Pleuronectes platessa. Mean percentage of the 0 group plaice population with respectively $0,1,2$ and $\geqslant 3$ cases of fin damage on the selected area on the tidal flats at high water in 1980

Although the spectrum becomes wider with increasing predator size, all shrimp size groups showed the largest number of prey in the smallest plaice size group.

In Table 3 mean mortality rates per week are calculated for the smallest size group, the newly-settled plaice $(\leqslant 15 \mathrm{~mm}$ ), which suffers the heaviest predation. The number of otoliths found in each catch was expressed in numbers of plaice consumed per day after a correction for digestion time. Data for the effect of temperature on digestion was kindly provided by Dr. M. Fonds (pers. comm.) and, applied to the results of
Table 1. Pleuronectes platessa. $\chi^{2}$ test of goodness of fit between observed frequency distribution of fin damage among newly-settled plaice on the selected quadrat during a number of weeks in 1980 and expected Poisson distribution with $\mu=$ mean no. of fin wounds per fish observed $\left(\chi_{0.05[3]}^{2}=7.82\right)$

\begin{tabular}{|ccc|}
\hline $\begin{array}{c}\text { Date } \\
(1980)\end{array}$ & $\begin{array}{c}\text { Mean no. of wounds } \\
(\mu)\end{array}$ & $\begin{array}{c}\chi^{2} \\
(\mathrm{df}=3)\end{array}$ \\
\hline $10 \mathrm{Mar}-14 \mathrm{Mar}$ & 0.96 & 5.95 \\
$17 \mathrm{Mar}-21 \mathrm{Mar}$ & 0.61 & 3.00 \\
$24 \mathrm{Mar}-28 \mathrm{Mar}$ & 0.86 & 0.82 \\
$31 \mathrm{Mar}-3 \mathrm{Apr}$ & 0.54 & 4.05 \\
$7 \mathrm{Apr}-11 \mathrm{Apr}$ & 0.82 & $9.60^{\circ}$ \\
$14 \mathrm{Apr}-18 \mathrm{Apr}$ & 0.47 & 1.75 \\
$21 \mathrm{Apr}-25 \mathrm{Apr}$ & 1.32 & 0.71 \\
$28 \mathrm{Apr}-2 \mathrm{May}$ & 0.67 & 5.95 \\
$5 \mathrm{May}-9 \mathrm{May}$ & 0.96 & 4.87 \\
- Significantly different distributions \\
\hline
\end{tabular}

Table 2. Crangon crangon/Pleuronectes platessa. Number of stomachs examined and the number of consumed plaice observed based on otoliths found for various size groups of predatory shrimps during the period of settlement of plaice in 1980

\begin{tabular}{|ccc|}
\hline $\begin{array}{c}\text { Shrimp size } \\
(\mathrm{mm})\end{array}$ & $\begin{array}{c}\text { No. of stomachs } \\
\text { examined }\end{array}$ & $\begin{array}{c}\text { No. of plaice } \\
\text { found }\end{array}$ \\
\hline $31-35$ & 264 & 11 \\
$36-40$ & 598 & 30 \\
$41-45$ & 755 & 31 \\
$46-50$ & 724 & 40 \\
$51-55$ & 300 & 15 \\
$>56$ & 138 & 18 \\
Total & 2379 & 145 \\
\hline
\end{tabular}


Table 3. Crangon crangon/Pleuronectes platessa. Stomach content analysis of predatory shrimps during the period of settlement of plaice in 1980. Results are pooled per week. For further explanation see text

\begin{tabular}{|ccccccc|}
\hline $\begin{array}{c}\text { Date } \\
(1980)\end{array}$ & $\begin{array}{c}\text { No. of } \\
\text { catches }\end{array}$ & $\begin{array}{c}\text { Total no, of } \\
\text { plaice } \leqslant 15 \mathrm{~mm}\end{array}$ & $\begin{array}{c}\text { Total no. of } \\
\text { otoliths found }\end{array}$ & $\begin{array}{c}\text { Temperature } \\
\left({ }^{\circ} \mathrm{C}\right)\end{array}$ & $\begin{array}{c}\text { Digestion time } \\
(\mathrm{h})\end{array}$ \\
\hline $10-14 \mathrm{Mar}$ & 16 & 410 & 27 & 5.0 & 24 & 0.068 \\
$24-28 \mathrm{Mar}$ & 17 & 880 & 19 & 3.5 & 3.5 & 20 \\
7-11 Apr & 14 & 377 & 23 & 7.0 & 0.016 \\
$21-25 \mathrm{Apr}$ & 16 & 563 & 17 & 10.0 & 8 & 0.053 \\
$5-9 \mathrm{May}$ & 17 & 488 & 22 & & 0.145 \\
\hline
\end{tabular}

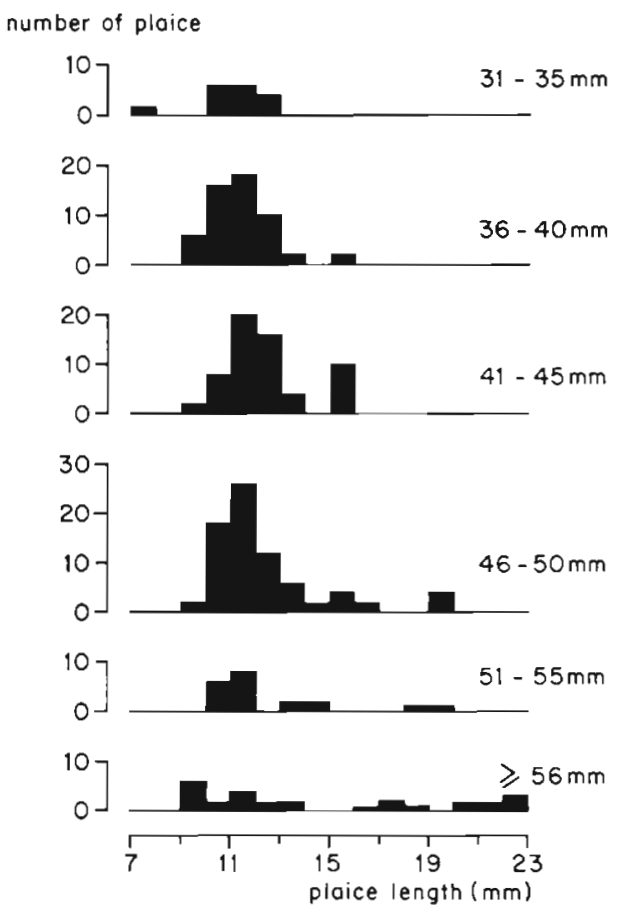

Fig. 13. Pleuronectes platessa/Crangon crangon. Size frequency distribution $(\mathrm{mm})$ of plaice consumed by various size groups of shrimps, estimated from otolith (sagitta) sizes found in the stomachs of shrimps on the selected rectangle in MarApr 1980

the digestion experiment at $18^{\circ} \mathrm{C}$, revealed the relation shown in Fig. 14. The numbers of plaice $\leqslant 15 \mathrm{~mm}$ and the numbers consumed per day of all catches were pooled and per week a mean daily mortality rate was estimated according to:

$$
Z=\ln \frac{\left(N_{t}-N_{c}\right)}{N_{t}}\left(d^{-1}\right)
$$

in which $N_{1}=$ the sum of the number of plaice $\leqslant 15$ $\mathrm{mm}$ in all catches examined on shrimp stomachs; and $\mathrm{N}_{\mathrm{c}}=$ total number of plaice consumed per day, based on the otoliths found in the shrimp stomachs in those catches and corrected for differences in digestion time. No systematic differences could be observed between day and night-time catches. Otoliths were found espe-

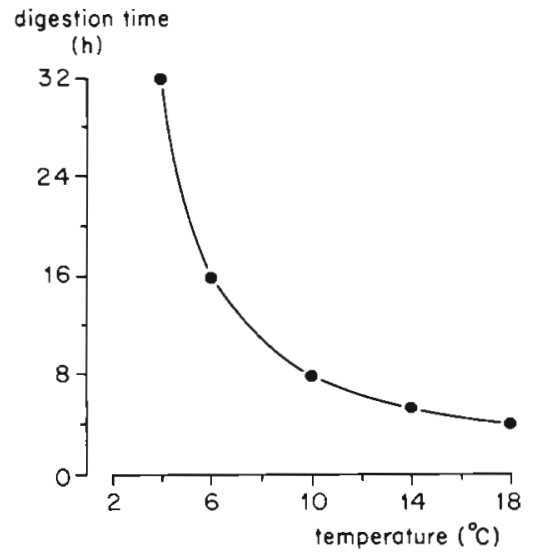

Fig. 14. Crangon crangon/Pleuronectes platessa. Relation between digestion time (h) of plaice and temperature for shrimps in size between 41 and $45 \mathrm{~mm}$ as deduced from Fig. 4 and personal information by Dr. M. Fonds

cially in plaice from the tidal flats at high tide and the gully and channel at high and low tide (Table 4). During the period of settlement until May, mean daily mortality rate fluctuated between 0.015 and $0.08 \mathrm{~d}^{-1}$. In May this mortality rate increased abruptly to $0.15 \mathrm{~d}^{-1}$, probably partly due to some immigration of large shrimps into the gullies (see Fig. 10), but mainly due to the fast rise in temperature affecting digestion rate and hence food intake of the predators. For the

Table 4. Pleuronectes platessa/Crangon crangon. Number of plaice found in the stomachs of predatory shrimps on the inner lake, drained tidal flats, tidal gully and tidal channel during day and night in high and low water catches during the period of settlement in 1980

\begin{tabular}{|lrrrr|} 
& \multicolumn{2}{c}{ Day } & \multicolumn{2}{c|}{ Night } \\
& High & Low & High & Low \\
& water & water & water & water \\
\hline Inner lake & 22 & 2 & 19 & 0 \\
Drained flats & 6 & 0 & 7 & 1 \\
Tidal gully & 4 & 29 & 5 & 42 \\
Tidal channel & 0 & 2 & 0 & 6 \\
\hline
\end{tabular}


period of settlement before May this daily mortality seemed to be density-dependent and related to the abundance of the newly-settled plaice on the tidal flats of the selected quadrat at high water (Fig. 15).

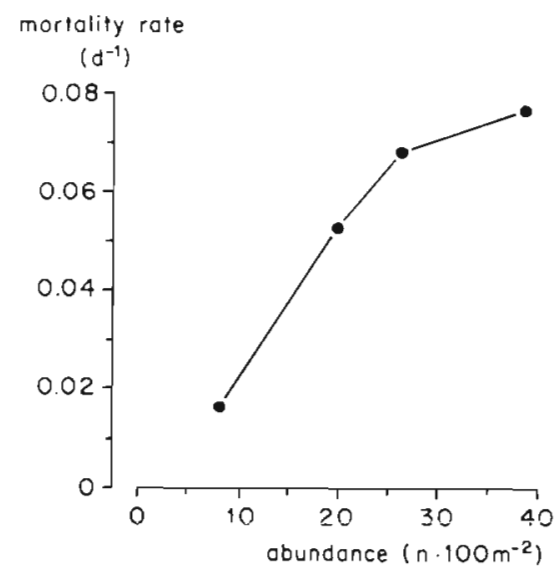

Fig. 15. Pleuronectes platessa. Mean daily mortality rate $\left(\mathrm{d}^{-1}\right)$ of newly-settled plaice due to predation, estimated from stomach content analysis of shrimps, in relation to the mean abundance of newly-settled plaice on the tidal flats of the selected quadrat at high water during the period of settlement in 1980

\section{DISCUSSION}

\section{Mortality factors}

The change in abundance of 0 -group plaice on the tidal flats of the Balgzand follows a similar pattern each year. From February onwards, densities increase to 200 to 500 ind $1000 \mathrm{~m}^{-2}$ at the end of April. Then, the population declines to about 100 ind $1000 \mathrm{~m}^{-2}$. Thereafter densities remain fairly constant until the emigration to deeper water starts in September (Kuipers 1977. Zijlstra et al. 1982, van der Veer 1986). Concerning the estimated mortality rates, the first year of life after settlement can be divided into 2 parts: a period of high, density-dependent mortality until May, followed by a period with rather low mortality without any signs of density-dependence (Zijlstra et al. 1982, van der Veer 1986).

Density-dependent mortalities in 0-group plaice have also been recorded in a number of British bays (Lockwood 1980). However, in those areas densitydependent mortality lasted the whole summer and was thought to be caused mainly by larger fish (Riley \& Corlett 1966, Macer 1967, Edwards \& Steele 1968). In a few areas evidence for some predation by shrimps has been found (Macer 1967. Edwards \& Steele 1968). In the Balgzand the period with density-dependent mortality is relatively short (van der Veer 1986), but esti- mated daily mortality rates are considerably higher than those found in British bays (Lockwood 1980) and the German Wadden Sea (Berghahn 1986). The main mortality factor on the Balgzand is clearly predation by the brown shrimp Crangon crangon.

The direct proof for shrimp predation on the Balgzand is the presence of plaice otoliths in the stomachs of shrimps during the period March to May. The level of predation deduced from these observations is sufficiently high to account for the daily mortality rates for the whole Balgzand area given in a previous paper (van der Veer 1986). According to the calculations based on the occurrence of plaice otoliths in shrimp stomachs in combination with digestion rates and the local density of plaice (Table 3), shrimp predation could cause a daily instantaneous mortality rate of between 0.02 and $0.15 \mathrm{~d}^{-1}$, whereas the average daily mortality rate on the whole Balggzand plaice population in the early post-settling period was estimated at $0.023 \mathrm{~d}^{-1}$ by Zijlstra et al. (1982) and at about $0.06 \mathrm{~d}^{-1}$ by van der Veer (1986). Mortality through shrimp predation appears to be higher than the other estimates, which may be attributed to the fact that the estimate refers to a small area with a relatively high plaice and shrimp abundance. Additional support for the importance of shrimp predation was obtained in the laboratory experiments, which showed that shrimps are able to prey on plaice of up to $30 \mathrm{~mm}$ in size. These observations agree with the conclusion that in the field the period of high mortality is restricted to the period before the end of May or early June, when the plaice population has reached a mean length of about $30 \mathrm{~mm}$ (Zijlstra et al. 1982, van der Veer 1986). The fin damage, which the experiments indicated to be caused by unsuccessful attacks, points in the same direction. The percentage of fish with damaged fins on the Balgzand decreases gradually within $50 \mathrm{~d}$ after early May, the estimated time for complete recovery according to experimental results. The distributions of both small plaice and predatory shrimps show that during the whole early post-settling period from March-May interactions between prey and predators are frequently possible.

The high level of predation by shrimps in comparison to estimates of total mortality tends to exclude a significant contribution of other causes of mortality during the period of settlement from February to May. There are no indications for starvation-induced mortality, since dead plaice have never been found, either by Creutzberg et al. (1978) and van der Veer (1985) in plankton catches, or in beam-trawl catches on the Balgzand. Also diseased 0-group plaice inflicted by for instance Vibrio spp. have never been reported during spring. This does not necessarily mean that such factors have no impact, since their effect might become 
masked by increased vulnerability to the shrimp. In British waters serious cannibalism has been reported (Riley \& Corlett 1966, Macer 1967), but on the Balgzand it was not observed by Kuipers (1977) in a comprehensive study of the food of plaice, whereas de Vlas (1979) reported only 2 cases in an extensive analysis of stomach contents of plaice. Therefore, in the Wadden Sea cannibalism would seem of minor importance. Larger crabs might inflict some mortality on the plaice population, but the effect must be limited, as they do not appear before June and restrict their predation to plaice smaller than about $5 \mathrm{~cm}$.

\section{Response of predator to fluctuating plaice densities}

According to the definitions of Solomon (1949), density-dependent regulation of a prey by a predator can either be caused by a functional response, by which each predator attacks more prey of a particular species as its density rise, or by a numerical response, by which the number of predators increases at higher prey densities.

In the rather short period of regulation in plaice, an actual real numerical response of the shrimp by reproduction is out of the question. Newly-hatched shrimp larvae need at least a few months to become predators on plaice at the minimum length of $30 \mathrm{~mm}$ (Kuipers \& Dapper 1984). A possible numerical response could be that larger shrimps are attracted by high plaice densities, a suggestion which finds support in the relation between weekly mean plaice abundance and the abundance of the predatory shrimps (Fig. 16).

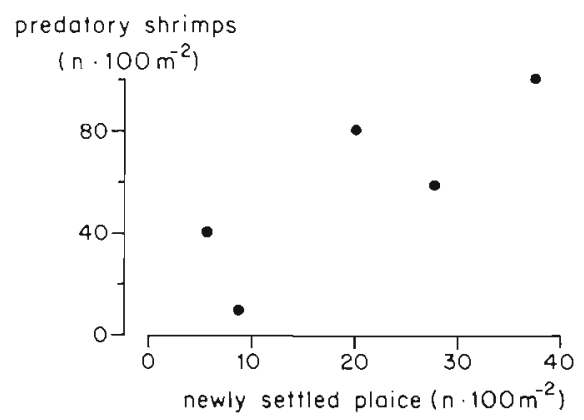

Fig. 16. Relation between abundance of newly-settled plaice (ind $100 \mathrm{~m}^{-2}$ ) and the density of predatory shrimps (ind $100 \mathrm{~m}^{-2}$ ) on the tidal flats of the selected rectangle during the weeks examined on shrimp stomach contents in 1980

Regulation of the plaice population by a functional response of the shrimps to fluctuating prey densities is also possible as suggested by the laboratory experiments. For a contribution to regulation the proportion of prey killed should increase with prey density over part of the density range (Solomon 1949, Holling 1959).
The results of the experiments suggest such a response; however, interpretation is hampered by the fact that 2 sizes of containers were used. If a functional response of the predator is involved, it is not immediately clear to what an individual shrimp actually responds. Certainly, the response of each predator size group will be different, because prey size spectra change with size of predator. Furthermore, the density and size spectrum of the plaice population constantly change during a tidal cycle, due to the tidal migrations of a gradually increasing part of the population.

For more insight into the response mechanism of the shrimps an integrated analysis and synthesis of the various aspects of predation is required. In the present study no attempt has been made to perform such an analysis. At present the regulation of the plaice population seems to be caused by the combined effect of both a functional and a numerical response of the predatory shrimps. At the end of the period of settlement the effect of this response is overshadowed by the effect of increased temperature, affecting food intake by reducing digestion time. In the predation process learning by the plaice seems unimportant, as an escape from an attack by a shrimp (indicated by fin damage) does not increase its chance of preventing a next encounter or to escape from a next attack.

Due to cyclical changes in the abiotic environment the predation process will probably exhibit cyclic patterns, since food intake by shrimps seems to take place especially around twilight both in the morning and the evening (Janssen 1980) and since both prey and predator perform tidal migrations. However, the present material does not allow further proof of the effect of light and tidal cycle.

\section{Effect of shrimp predation on year-class strength of plaice}

The density-dependent mortality by shrimp predation found within years will also operate between years. The observed reduction of variation in yearclass strength between years occurring during and shortly after settlement in the Wadden Sea, as described in a previous paper on mortality of plaice (van der Veer 1986), may therefore mainly be the result of this shrimp predation. There are some indications that this regulative mechanism in the nursery fails after a strong winter. After low temperatures on the spawning grounds in the southern North Sea, strong year-classes of plaice seem to be generated, as is suggested by the inverse relation between year-class strength of plaice and temperature conditions on the spawning ground (Zijlstra \& Witte 1985, van der Veer 1986). The extremely strong year-class after the severe 
winter of 1963 (Rauck \& Zijlstra 1978) supports this view. After such a cold winter, with ice coverage of the Wadden Sea, the abundance of the predatory shrimps was strongly reduced by a delayed return of emigrated ones (Boddeke 1963). As a result such a strong yearclass will pass through this period of density-dependent mortality in the Wadden Sea relatively unharmed.

In other parts of the Wadden Sea this regulation of plaice by Crangon crangon may also take place, since the predator $C$. crangon is present in almost the whole area. An indication that this predator-prey relation may be a more common feature in coastal waters even outside the Wadden Sea is provided by the work of Arndt \& Nehls (1964) in the Baltic, showing photographs of small plaice with fin damage in the presence of shrimps, which, however, the authors did not recognize as such.

Acknowledgements. Thanks are due to J. IJ. Witte for assistance during sampling, to J. J. Zijlstra for his guidance and to G. P. Baerends, F. Creutzberg, N. Daan, R. N. Gibson, B. R. Kuipers and Mrs. G. van der Wolf for critical reading of the manuscript. These investigations were supported by the Foundation for Fundamental Biological Research (BION), which is subsidized by the Netherlands Organization for the Advancement of Pure Research (ZWO).

\section{LITERATURE CITED}

Arndt, E. A., Nehls, H. W. (1964). Nahrungsuntersuchungen an Postlarvalstadien und Jungtieren von Pleuronectes flesus L. und Pleuronectes platessa L in der äußeren Wismarer Bucht. Zeitsch. für Fischerei Band XII N.F. Heft 1/2: 45-73

Bannister, R. C. A. (1978). Changes in plaice stocks and plaice fisheries in the North Sea. Rapp. P.-v. Réun. Cons. int Explor. Mer 172: 86-101

Berghahn, R. (1983). Untersuchungen an Plattfischen und Nordseegarnelen (Crangon crangon) im Eulitoral des Wattenmeeres nach dem Übergang zum Bodenleben. Helgoländer Meeresunters. 36: 163-181

Berghahn, R. (1986). Determining abundance, distribution and mortality of 0 -group plaice (Pleuronectes platessa $\mathrm{L}$.) in the Wadden Sea. J. appl. Ichthyol. 2: 11-22

Bergman, M., Kuipers, B., Spliethoff, P., Veer, H. van der (1976). Garnalen en krabben als mogelijke predatoren van 0-jarige schol op het Balgzand. Visserij 29: 432-438

Beverton, R. J. H. (1961). Long-term dynamics of certain North Sea fish populations. In: Le Cren, E. D., Holdgate, M. W (ed.) The exploitation of natural animal populations. Blackwell Scientific Publications, Oxford, p. 242-264

Boddeke, R. (1963). De invloed van de strenge winter 1962-1963 op de gamalenstand. Visserij 16: 126-128

Brander, K., Houghton, R. G. (1982). Predicting the recruitment of North Sea plaice from egg surveys. Coun. Meet. int. Coun. Explor. Sea C.M.-[CES/G: 5

Bückmann, A. (1934). Über die Jungschollenbevölkerung der Deutschen Wattenküste der Nordsee. Ber dt. wiss. Kommn Meeresforsch. 7: 320-327

Creutzberg, F., Eltink, A. Th. G. W., Noort, G. J. van (1978). The migration of plaice larvae Pleuronectes platessa into the western Wadden Sea. In: McLusky, D. S., Berry, A. J. (ed.) Physiology and behaviour of marine organisms. Proceedings 12th European Marine Biological Symposium, Pergamon Press, Oxford, p. 243-252

Dapper, R. (1978). De Balgzand scholgegevens 1975, 1976 1977. Interne Verslagen Nederlands Instituut voor Onderzoek der Zee, Texel 1978-12: 1-53

Edwards, R., Steele, J. H. (1968). The ecology of 0-group plaice and common dab at Loch Ewe. I. Population and food. J. exp. mar. Biol. Ecol. 2: 215-238

Harding, D., Nichols, J. H., Tungate, D. S. (1978). The spawning of plaice (Pleuronectes platessa L.) in the southern North Sea and English Channel. Rapp. P.-v. Réun. Cons. int. Explor, Mer 172: 102-113

Holling, C. S. (1959). The components of predation as revealed by a study of small-mammal predation of the European Pine Sawfly. Can. Entom. 91: 293-320

Janssen, G. M. (1980). De voedselopname van de gamaal Crangon crangon. Interne Verslagen Nederlands Instituut voor Onderzoek der Zee, Texel 1980-3: 1-34

Kuipers, B. R. (1975). On the efficiency of a two meter beam trawl in juvenile plaice (Dleuronectes platcssa). Ncth. J. Sea Res. 9: $69-85$

Kuipers, B. R. (1977), On the ecology of juvenile plaice on a tidal flat in the Wadden Sea. Neth. J. Sea Res. 11: 56-91

Kuipers, B. R., Dapper, R. (1981). Production of Crangon crangon in the tidal zone of the Dutch Wadden Sea. Neth. J. Sea Res. 15: 33-53

Kuipers, B. R., Dapper, R. (1984). Nursery aspects of Wadden Sea tidal flats for the brown shrimp Crangon crangon. Mar. Ecol. Prog. Ser. 17: 171-181

Lockwood, S. J. (1972). An ecological survey of an 0-group plaice (Pleuronectes platessa L.) population, Filey Bay, Yorkshire. Thesis, Univ. of East Anglia

Lockwood, S. J. (1980). Density-dependent mortality in 0group plaice (Pleuronectes platessa L.) populations. J. Cons. int. Explor. Mer 39: 148-153

Macer, C. T. (1967). The food web in Red Wharf Bay (North Wales) with particular reference to young plaice (Pleuronectes platessa). Helgoländer wiss. Meeresunters. 15: $560-573$

Rauck, G. (1974). The arrival of different groups of young plaice in the German Wadden Sea. Ber. dt. wiss. Kommn Meeresforsch. 23: 273-288

Rauck, G., Zijlstra, J. J. (1978). On the nursery aspects of the Wadden Sea for some commercial fish species and possible long-term changes. Rapp. P.-v. Réun. Cons. int. Explor. Mer 172: 226-275

Riley, J. D., Corlett, J. (1966). The numbers of 0-group plaice in Port Erin Bay 1964-66. Rep. mar. biol. Stn Port Erin 78: 51-56

Simpson, A. G. (1959). The spawning of the plaice in the North Sea. Fishery Invest. Lond. Ser. 2, 22 (7): 1-111

Solomon, M. E. (1949). The natural control of animal populations. J. Anim. Ecol. 18: 1-35

Talbot, J. W. (1976). The dispersal of plaice eggs and larvae in the southern Bight of the North Sea. J. Cons. int. Explor Mer 37: 221-248

Talbot, J. W. (1978). Changes in plaice larval dispersal in the last fifteen years. Rapp. P.-v. Réun. Cons. int. Explor. Mer 172: $114-123$

Veer, H. W. van der (1985). Impact of coelenterate predation on larval plaice Pleuronectes platessa and flounder Platichthys flesus stock in the western Wadden Sea. Mar. Ecol. Prog. Ser. 25: 229-238

Veer, H. W. van der (1986). Immigration, settlement and density-dependent mortality of a larval and early postlar- 
val 0-group plaice Pleuronectes platessa population in the western Wadden Sea. Mar. Ecol. Prog. Ser. 29: 223-236

Veer, H. W. van der, Bergman, M. J. N. (1986). Development of tidally related behaviour of a newly settled 0-group plaice (Pleuronectes platessa L.) population in the western Wadden Sea. Mar. Ecol. Prog. Ser. 31: 121-129

Vlas, J. de (1979). Annual food intake by plaice and flounder in a tidal flat area in the Dutch Wadden Sea, with special reference to consumption of regenerating parts of macrobenthic prey. Neth. J. Sea Res. 13: 117-153

Zijlstra, J. J. (1972). On the importance of the Waddensea as a nursery area in relation to the conservation of the southern
North Sea fishery resources. Symp. zool. Soc. Lond. 29: $233-258$

Zijlstra, J. J., Dapper, R., Witte, J. IJ. (1982). Settlement, growth and mortality of post-larval plaice (Pleuronectes platessa) in the western Wadden Sea. Neth. J. Sea Res. 15: 250-272

Zijlstra, J. J., Witte, J. IJ. (1982). On the relation between length and abundance in 0-group plaice of the North Sea. Coun. Meet. int. Coun. Explor. Sea C.M.-ICES/G: 4

Zijlstra, J. J., Witte, J. IJ. (1985). On the recruitment of 0group plaice in the North Sea. Neth. J. Zool. 35: 360-376

This article was submitted to the editor; it was accepted for printing on November 24, 1986 